\title{
Investability, corporate governance and firm value
}

\section{Thomas O'Connor*}

Department of Economics, Finance and Accounting, National University of Ireland Maynooth, Maynooth, Co. Kildare, Ireland

\section{A R T I C L E I N F O}

\section{Article history:}

Received 21 February 2011

Received in revised form 7 September 2011

Accepted 10 September 2011

Available online 16 September 2011

Dedicated to the memory of my baby daughter Orla.

\section{JEL classification:}

G15, G34, F36

Keywords:

Investability

Corporate governance

Tobin's $q$

\begin{abstract}
A B S T R A C T
In this paper, I show that "investable premia" are greatest for transparent, well-governed firms. I find that single-class share investable firms and better-governed firms reap the largest valuation gains from becoming investable. Dual-class share firms do gain from becoming investable, but their gains are much lower than that of single-class share firms. These findings suggest that the failure on the part of firms to remedy agency conflicts prior to becoming investable only serves to greatly reduce, or even nullify their "investable premia".
\end{abstract}

(C) 2011 Elsevier B.V. All rights reserved.

\section{Introduction}

Over the course of the last three decades, emerging markets as currently designated, have, using stock market liberalizations opened up their domestic firms to foreign ownership. For example, using the official liberalization dates provided by Bekaert and Harvey (2000), Portugal (1986), Greece (1987), Thailand (1987), followed by Malaysia (1988), and Morocco (1989) were amongst the first emerging markets to liberalize their stock markets. Since then, others have followed, including Argentina (1989), Brazil (1991), and India (1992). More recently, countries such as Tunisia (1995) and South Africa (1996) have followed suit. Subsequently, a large literature has shown that this type of financial liberalization reform has proved beneficial. At the firm-level and consistent with international asset pricing models, stock market liberalizations tend to reduce the cost of equity capital as a result of greater

\footnotetext{
* Corresponding author. Tel.: +3531 7086667.

E-mail address: thomas.g.oconnor@nuim.ie
} 
risk sharing between domestic and foreign investors. In turn, this has resulted in reduced financing constraints (Kim and Signal, 2000), increased investment (Henry, 2000; Mitton, 2006 using firm-level data), improved operating performance (Mitton, 2006), and enhanced stock prices (Chari and Henry, 2004). Perhaps then not surprisingly, Mitton and O'Connor (2011) show that these realized gains impact positively on the value of these firms. Using Tobin's $q$ to proxy for firm value, they uncover an "investable premium" in the region of $9 \%$ for investable firms. At the country (aggregate) level, such reforms have resulted in greater investment and ultimately economic growth (Bekaert et al., 2001, 2005; Gupta and Yuan, 2009).

However, with some exceptions (Mitton, 2006; Mitton and O'Connor, 2011), much of this analysis has been performed with the average firm in mind, which potentially ignores the heterogeneous effects that financial liberalization has across firms, since firms with the most to gain from becoming investable e.g., firms with sizable financing constraints, are likely to benefit the most. Consistent with this view, Mitton and O'Connor (2011) show that the greatest valuations gains from stock market liberalizations accrue to financially constrained firms (as measured using investment-cashflow sensitivities (Fazzari et al., 1988)). Furthermore, the ability of firms to attract outside/foreign investment is in large part contingent on their ability to convince outsider investors that expropriation risk is low. Since investors tend to invest in transparent, well-governed firms (Leuz et al., 2009; Aggarwal et al., 2005), this then suggests that the greatest gains to financial liberalization should accrue to transparent, well-governed firms, where the consumption of private benefits is low. In contrast, poorly governed firms are likely to gain very little or potentially nothing at all from financial liberalization. Hence, the "investable premium" is likely to be much higher for transparent, well-governed firms. In this paper, I test this proposition. Specifically, I examine, whether the "investable premium" documented by Mitton and O'Connor (2011) is greatest for these transparent, well-governed firms.

To do so, I form a panel of 1510 firms: 251 investable and 1259 non-investable firms, and use Tobin's $q$ to proxy for firm value. While on average, corporate governance practices tend to be less transparent in emerging markets (relative to firms in developed countries), sizable variation in corporate governance practices exists both across and within emerging market countries (Klapper and Love, 2004; Durnev and Kim, 2005). To capture this variation in governance practices across firms and countries, I use three different measures commonly employed in other studies. The first classifies firms as either dual- or single-class share firms. Typically, single-class share firms are more transparent and better-governed than dual-class share firms (Durnev and Kim, 2005; Masulis et al., 2009). In the case of the latter, insiders posses sizable control rights without commensurate cashflow rights, by holding shares with greater voting rights. In this instance, controlling insiders create a 'wedge' between their voting and cashflow rights, creating a situation whereby expropriation is costly for minority outsiders, and ultimately beneficial for the controlling insiders. A large literature suggests that outsiders, most notably institutional investors are reluctant to invest in such firms (Leuz et al., 2009; Aggarwal et al., 2005; Li et al., 2008). ${ }^{1}$ Thus, a priori, I would expect that single-class share investable firms would reap large valuation gains from becoming investable, both on an absolute basis, and relative to dual-class firms. Whether dual-class share firms reap any valuation gains is an open empirical question. Recent work suggests that dual-class firms experience permanent valuation gains from another aspect of internationalizations, namely international cross-listings (King and Segal, 2009). However, they do so through legal bonding arising from cross-listing in the U.S. ${ }^{2}$ While equity market liberalizations are associated with improvements in firms' information environment (Bae et al., 2006); they are not

\footnotetext{
${ }^{1}$ Recent work has focused on examining the governance preferences of institutional investors (McCahery et al., 2009; Bushee et al., 2007; Ferreira and Matos, 2008). These papers find that institutional investors have both a preference for well-governed firms, and a desire to improve this governance through what is commonly referred to as "shareholder activism". For a review of the governance role played by institutional investors, see Gillan and Starks (2003). Recent work questions the governance role played by institutional investors in the current financial crisis. Banks with high institutional ownership performed worse than banks with less institutional ownership, because institutional investors encouraged greater risk-taking prior to the crisis (Erkens et al., 2010).

2 King and Segal (2009) show that bonding alone is sufficient for dual-class Canadian firms to reap a permanent "cross-listing premium".
} 
accompanied with any formal bonding mechanism. ${ }^{3}$ Thus, absent bonding, dual-class investable firms are likely to reap little valuation gains, since risk sharing through an expansion of their shareholder base is likely to be minimal. ${ }^{4}$ Second, I use two measures, which gauge the extent of agency costs in a firm, namely the ratio of sales-to-assets, and operating expenses-to-sales. Since agency costs are decreasing (increasing) in the former (latter), a priori, I would expect that the greatest valuation gains accrue to firms with a high sales-to-assets ratio, and a low operating expenses-to-sales ratio.

This is exactly what I find. I begin by reconfirming the findings of Mitton and O'Connor (2011). For the average firm, investability increases firm value in the region of $10.5 \%$. In turn, I show that this "investable premium" is greatest for single-class share firms. Dual-class share firms do not experience an "investable premium", relative to other single- and dual-class non-investable firms, but do so relative to their counterpart non-investable dual-class firms. Next, using the agency cost measures; I find that better-governed firms experience the largest "investable premia". All in all, these findings are consistent with a large literature, which shows that investors are less likely to invest in poorly governed firms (Leuz et al., 2009; Aggarwal et al., 2005), and appear to confirm Stulz (2005) assertion that the gains from financial globalization (stock market liberalizations in this instance) are limited by what he refers to as the agency problem of "corporate insider discretion". Here the agency cost arises since insiders run the firm in their own best interests, and not in the interests of outside minority shareholders. Consequently outsiders/institutional investors are less likely to invest in these firms. The result is that poorly-governed firms and dual-class share firms in particular gain little, or at least in the case of the latter, much less than their single-class share counterparts. As a result, these findings suggest that firms should improve their governance prior to becoming investable in order maximize the subsequent valuation gains. Since stock market liberalizations tend to occur when financial markets are already well-developed (Kim and Kenny, 2007), and the costs of improving corporate governance tend to be much lower as a result (Doidge et al., 2007), then the net effect (i.e. the benefits of becoming investable less the costs of corporate governance improvements prior to becoming investable) of becoming investable is still likely to be positive. ${ }^{5}$

The paper proceeds as follows. In the next section I describe the data used in the study. In Section 3 I report results on the relation between investability, corporate governance and firm value. Section 4 concludes.

\section{Data}

I begin by sourcing an initial sample of all 2784 firms from the major markets of the IFC Emerging Market Database (EMDB) that were deemed investable at any time between 1980 and 2000. Like Mitton (2006) and Mitton and O'Connor (2011), I measure the openness of a firm's stock to foreign investors using the "investable" measure provided by the EMDB. The IFC designates a firm as investable if its stock is free from both country-level and firm-level restrictions on foreign investment. It also requires that the stocks have sufficient size and liquidity to be realistically available to foreign investors. I define a firm as investable in a given year if the firm's stock appears in the IFC investable index by December of that year. As a secondary measure of openness I use the "degree-open" investable measure, a continuous variable ranging from zero (not open to foreign investors) to one (fully open to foreign investors). As noted by Edison and Warnock (2003), there are limitations to use these measures. However, like Mitton and O'Connor (2011), I do not believe that they introduce any significant biases in the tests performed in this paper. The sample covers the period from 1980 to 2000.

\footnotetext{
${ }^{3}$ Lang et al. (2003) relate the valuation gains from cross-listing in the U.S. to improvements in firms' information environment (i.e. increased analyst following and improved forecast accuracy). Thus, even absent bonding, (voluntary) improvements in a firm's information environment may be sufficient to generate an "nvestable premium".

${ }^{4}$ Of course, this does not rule out the possibility that these firms may be able to attract foreign investors by voluntarily providing better disclosures and improving their corporate governance. Along these lines, Hope et al. (2010) show how crosslisting firms not mandated to provide greater disclosures (i.e. Level 1/Rule 144a firms) actually provide more frequent and higher quality disclosures than Level $2 / 3$ firms who are mandated to do so.

${ }_{5}$ Along similar lines, Kling and Weitzel (2011) and Chiang and Lo (2009) explore the relationship between corporate governance and internationalizations for Chinese and Taiwanese firms, respectively.
} 
To be included in the final sample, firms must have financial data available in the Worldscope database and satisfy a number of minimum-data requirements. First, I require that firms that become investable in the sample period have financial data available at least 1 year before and one year after the year in which they are first deemed investable. ${ }^{6}$ Second, firms that never become investable are required to have financial data available one year either side of the median year in which firms are first investable in their respective countries. ${ }^{7}$ After imposing these requirements, I lose, from my initial sample, all firms from the Czech Republic, Egypt, Hungary, Jordan, Morocco, Poland, Russia, Sri Lanka, Slovakia, Venezuela and Zimbabwe since all firms from these countries fail to satisfy the minimum data requirements. My final sample outlined in Table 1 consists of 251 investable firms from twenty countries, namely, Argentina, Brazil, Chile, China, Colombia, Greece, India, Indonesia, Israel, Korea (Republic), Malaysia, Mexico, Pakistan, Peru, Philippines, Portugal, South Africa, Taiwan, Thailand, and Turkey. The total number of non-investable firms is 1259 , which when added to the 251 investable firms results in a final sample of 1510 firms. In Table 1, I outline by country, the number of investable (\# Inv) and non-investable (\# NI) firms, the number of firm-year observations (\# Obs), and the total number of firms (\# Total). The number of sample firms per country varies significantly, ranging from a minimum of 8 in Colombia (Corresponding to 63 firm-year observations) to a high of 223 in Malaysia (Corresponding to 1671 firm year observations). Korea provides the greatest number of investable firms (56), while Indonesia provides just one. The total number of firm-year observations is 9992.

Table 1 also presents three key dates for each country: namely, the first year in which the sample of firms in each country are designated investable (First Inv); the first year in which a closed-end country fund is available for each country (Country Fund); and the first year in which a sample firm in each country cross-lists in the United States as an American Depositary Receipt (First ADR). Country fund data is sourced from Bekaert et al. (2005) and Patro (2005). All information on cross-listed firms is sourced from the Bank of New York, and cross-referenced with information from Deutsche Bank, JP Morgan, the New York Stock Exchange, and NASDAQ. I take great care in order to identify a firm's initial listing. To do so, I consult the historical records from the Bank of New York (since the currently available on-line records refer to a firm's current - not previous/initial - cross-listing). I cross-reference this data with the cross-listing database provided by Citibank. They flag firms that have changed their cross-listing status by including a "successor depositary receipt" data type for all firms. South Africa (18) and Mexico (14) provide the greatest number of cross-listing firms.

I employ Tobin's $q$ to measure firm value, where Tobin's $q$ is defined as the book value of debt plus market capitalization divided by the book value of assets. Market value of debt is proxied using its book value counterpart, and the replacement cost of assets as the book value of assets. Book value of debt is calculated as the book value of total assets less the book value of equity. These simplifications are unavoidable. Doidge et al. (2004, 2009), Gozzi et al. (2008), and Mitton and O'Connor (2011) all use Tobin's $q$ to proxy for firm value in their studies on the valuation effects of international cross-listings, internationalizations, and investability, respectively. Furthermore, all three calculate Tobin's $q$ exactly as I do. All firm-level financial information is sourced from Worldscope for each year from 1980 to 2000. I control for firm and industry related factors commonly employed in other studies using Tobin's $q$. I use the average (geometric) sales growth (inflation-adjusted) over the last two years and global industry $q$ to account for firm and industry growth, respectively. Based upon the general industry classification codes provided by Worldscope, the (yearly) mean global industry $q$ is calculated as the average $q$ of all global firms within each classification. The general industry classification codes are; 1 (Industrial), 2 (Utility), 3 (Transportation), 4 (Bank/Savings and Loan), 5 (Insurance), 6 (Other Financial). I use the $\log$ of sales (inflation-adjusted and in \$U.S.), rather than total assets (given the definition of Tobin's q) to control for firm size. Like King and Segal (2009), I also control for firm leverage and profitability. Leverage is calculated as total debt to assets, and profitability as earnings before interest and taxation to total assets. Tobin's $q$, sales growth, firm size, leverage and profitability are winsorized at the 1 and $99 \%$ tails of the distribution to remove the confounding effects of outliers. Finally, I exclude financial firms since these firms are more likely to be valued differently from non-financial firms.

\footnotetext{
${ }^{6}$ There are firms in the final sample that become investable, subsequently become de-investable and investable once again. I require data to be available prior to their initial investable date.

7 The first year in which firms first become investable are presented in Table 1 for each country.
} 
Table 1

Sample statistics by country.

\begin{tabular}{|c|c|c|c|c|c|c|c|c|c|c|c|c|}
\hline & \multicolumn{4}{|c|}{ Sample } & \multicolumn{2}{|c|}{ Single and dual-class firms } & \multicolumn{2}{|c|}{ Agency costs } & \multirow[t]{2}{*}{ ADR } & \multicolumn{3}{|l|}{ Key dates } \\
\hline & \# Obs & \# Invest & \# NI & Total & Inv and SC & Inv and DC & $\mathrm{AC} 1$ & $\mathrm{AC} 2$ & & First invest & First ADR & Country fund \\
\hline Argentina & 75 & 3 & 9 & 12 & 2 & 1 & 0.37 & 0.86 & 0 & 1992 & - & 1991 \\
\hline Brazil & 363 & 9 & 44 & 53 & 1 & 8 & 0.95 & 0.94 & 7 & 1991 & 1994 & 1992 \\
\hline Chile & 265 & 11 & 30 & 41 & 9 & 2 & 0.50 & 0.85 & 5 & 1992 & 1993 & 1992 \\
\hline China & 313 & 2 & 68 & 70 & 0 & 2 & 0.59 & 2.15 & 1 & 1992 & 1995 & 1992 \\
\hline Colombia & 63 & 2 & 6 & 8 & 1 & 1 & 1.35 & 0.97 & 1 & 1991 & 1994 & 1992 \\
\hline Greece & 660 & 20 & 86 & 106 & 9 & 11 & 0.91 & 0.91 & 1 & 1988 & 1990 & 1998 \\
\hline India & 1123 & 12 & 185 & 197 & 12 & 0 & 0.72 & 0.91 & 10 & 1991 & 1993 & 1991 \\
\hline Indonesia & 496 & 1 & 78 & 79 & 0 & 1 & 0.41 & 0.84 & 1 & 1993 & 1996 & 1991 \\
\hline Israel & 91 & 6 & 11 & 17 & 6 & 0 & 0.52 & 0.92 & 0 & 1994 & - & 1994 \\
\hline Korea & 1317 & 56 & 120 & 176 & 56 & 0 & 0.74 & 0.93 & 10 & 1988 & 1991 & 1984 \\
\hline Malaysia & 1671 & 45 & 178 & 223 & 45 & 0 & 0.64 & 0.90 & 4 & 1988 & 1992 & 1987 \\
\hline Mexico & 329 & 15 & 21 & 36 & 4 & 11 & 0.65 & 0.86 & 14 & 1988 & 1991 & 1982 \\
\hline Pakistan & 303 & 3 & 51 & 54 & 3 & 0 & 0.62 & 0.88 & 0 & 1994 & - & 1994 \\
\hline Peru & 61 & 2 & 12 & 14 & 0 & 2 & 0.49 & 0.93 & 0 & 1993 & - & NA \\
\hline Philippines & 216 & 5 & 33 & 38 & 2 & 3 & 0.36 & 0.84 & 3 & 1993 & 1995 & 1990 \\
\hline Portugal & 280 & 9 & 30 & 39 & 7 & 2 & 0.98 & 0.97 & 2 & 1988 & 1990 & 1987 \\
\hline Sth Africa & 750 & 23 & 43 & 66 & 20 & 3 & 1.27 & 0.89 & 18 & 1982 & 1994 & 1994 \\
\hline Taiwan & 538 & 14 & 98 & 112 & 13 & 1 & 0.65 & 0.92 & 10 & 1990 & 1992 & 1990 \\
\hline Thailand & 874 & 7 & 129 & 136 & 0 & 7 & 0.89 & 0.93 & 0 & 1989 & 1999 & 1989 \\
\hline \multirow[t]{2}{*}{ Turkey } & 204 & 6 & 27 & 33 & 6 & 0 & 1.37 & 0.92 & 1 & 1991 & 1994 & 1990 \\
\hline & 9992 & 251 & 1259 & 1510 & 196 & 55 & 0.78 & 0.91 & 88 & & & \\
\hline
\end{tabular}

The table reports summary statistics of the sample by country. Investable dates are taken from the Emerging Markets Database (EMDB). \# Obs is the number of firm-year observations: \# Invest is the number of investable firms; \# NI is the number of non-investable firms, and \# Total is the total number of firms. Inv and SC and Inv and DC are the number of single and dual-class investable firms, respectively. AC1 and 2 are measures of the extent of agency costs. AC1 is measured as sales to assets and AC2 is operating expenses to sales. All information on ADRs is sourced from the Bank of New York, Citibank, NYSE, and NASDAQ. The number of ADRs refers to the number of firms with ADRs that also have post-listing financial data. First Invest and First ADR is the first year Investable and ADRs appear in the sample. First country fund dates are taken from Bekaert et al. (2005) and Patro (2005). 
To measure the strength of corporate governance, I use three different measures. The first is an indicator variable that takes the value of one if the firm is a dual-class share firm. A large literature has documented that since cash-flow and voting rights are separated under such a mechanism in these firms (in contrast to a one-share-one-vote system), the consumption of private benefits tends to be greater in firms with dual-class shares compared to firms with single-class share structures (DeAngelo and DeAngelo, 1985; Grossman and Hart, 1988, and more recently, Masulis et al., 2009). ${ }^{8}$ As a result, dual-class share firms tend to trade at a discount relative to single-class share companies (Lins, 2003; Durnev and Kim, 2005; Smart et al., 2008). I source this data item from Worldscope, using their 'Currently a Multiple Share Company' indicator which they define as "Currently a multiple share company indicates which companies currently have more than one type of common/ordinary share". The second and third corporate governance measures that I employ are measures, which gauge the extent of agency conflicts in a firm. The first is total (annual) sales divided by total assets, and is a measure of how effectively the firm's assets are deployed to generate (sales) revenue. Ang et al. (2000) theorize that agency costs decrease as this ratio increases. The third measure, also from Ang et al.(2000) is the ratio of operating expenses to annual sales. Since excessive prerequisite consumption and other agency costs are likely to manifest into higher operating expenses, higher values of this variable imply higher agency costs, and thus poorer corporate governance. Singh and Davidson (2003), Bartram et al. (2008) (in an earlier version of their paper) and McKnight and Weir (2009) use variants of these agency cost ratios in their respective studies. ${ }^{9}$ One potential drawback of using these agency cost measures in this context is that some studies also use Tobin's $q$ to measure agency costs. Here, agency costs are expected to decrease in Tobin's $q$. Consequently, the correlations amongst the agency cost proxies i.e., amongst Tobin's $q$ and the other variables may be driving my results. While I cannot definitively rule out this possibility, the correlations amongst the variables are small, and suggest that this may not be a major issue. For example, the correlation coefficient between Tobin's $q$ and (annual) sales to total assets is just 0.076 and -0.045 for Tobin's $q$ and operating expenses to annual sales. In addition, and in order to try and overcome this potential problem, I estimate in Table 6, separate regressions for firms with high and low pre-investable agency costs. If firms with low pre-investable agency costs (and thus presumably better governance) reap the largest gains from becoming investable, this then suggests that better governed firms reap the largest gains from becoming investable, and that this result is not 'mechanically' driven by the correlation amongst the variables in the post-investable period.

Table 1 displays the number of single and dual-class investable firms, and also the median value of the two agency cost ratios (calculated over the entire sample period) for our sample of investable firms, for each country. These summary measures suggest that corporations are better-governed in Colombia, South Africa, and Turkey (using sales-to-assets). In contrast, agency conflicts tend to be severe in China. Finally, 55 or $21.91 \%$ of the entire sample of investable firms are deemed dual-class share firms. Greece and Mexico provide the greatest number with 11 each. India, Pakistan, and Turkey contribute no dual-class share investable firm to the final sample.

\section{Investability, corporate governance and firm value}

This section presents the main results on the relationship between investability, corporate governance and firm value. I begin by first examining the relationship between investability and firm value as per Mitton and O'Connor (2011). I then estimate the joint-effect of investability and corporate governance on firm value.

\footnotetext{
${ }^{8}$ Durnev and Kim $(2005,2007)$ show using CLSA and S\&P corporate governance data that in firms where control rights exceed cashflow rights (e.g. dual-class share firms), corporate governance standards tend to be lower in these firms, relative to firms where no such differences (or much smaller differences) exist between control and cashflow rights (e.g. single-class share firms).

9 These agency cost proxies are employed as dependent variables (industry-adjusted) in the McKnight and Weir (2009) study, while Bartram et al. (2008) employ the ratios as independent variables in corporate total payout regressions.
} 
Table 2

Regression estimates of the effect of investability on firm value.

\begin{tabular}{|c|c|c|c|c|c|c|c|c|}
\hline & \multicolumn{8}{|c|}{ Investable dummies } \\
\hline & (1) & (2) & (3) & (4) & (5) & (6) & (7) & $(8)$ \\
\hline Investable & $\begin{array}{l}0.117^{* * *} \\
(3.15)\end{array}$ & $\begin{array}{l}0.120^{* * * *} \\
(3.22)\end{array}$ & $\begin{array}{l}0.132^{* * * *} \\
(3.60)\end{array}$ & $\begin{array}{l}0.136^{* * *} \\
(3.72)\end{array}$ & $\begin{array}{l}0.136^{* * *} \\
(3.72)\end{array}$ & $\begin{array}{l}0.125^{* * * *} \\
(3.43)\end{array}$ & $\begin{array}{l}0.139 * * * \\
(3.80)\end{array}$ & $\begin{array}{l}0.101^{* * * *} \\
(2.76)\end{array}$ \\
\hline Firm size & & $\begin{array}{l}-0.011 \\
(0.53)\end{array}$ & $\begin{array}{l}-0.073^{* * *} \\
(3.09)\end{array}$ & $\begin{array}{l}-0.073^{* * *} \\
(3.10)\end{array}$ & $\begin{array}{l}-0.074^{* * *} \\
(3.14)\end{array}$ & $\begin{array}{l}-0.079^{* * *} \\
(3.36)\end{array}$ & $\begin{array}{l}-0.077^{* * *} \\
(3.31)\end{array}$ & $\begin{array}{l}-0.097^{* * *} \\
(4.29)\end{array}$ \\
\hline Firm growth & & & $\begin{array}{l}0.825^{* * *} \\
(8.15)\end{array}$ & $\begin{array}{l}0.830^{* * * *} \\
(8.19)\end{array}$ & $\begin{array}{l}0.835^{* * *} \\
(8.28)\end{array}$ & $\begin{array}{l}0.696^{* * *} \\
(6.82)\end{array}$ & $\begin{array}{l}0.688^{* * *} \\
(6.77)\end{array}$ & $\begin{array}{l}0.624^{* * * *} \\
(6.21)\end{array}$ \\
\hline Global industry $Q$ & & & & $\begin{array}{l}1.065^{* * *} \\
(6.98)\end{array}$ & $\begin{array}{l}1.066^{* * * *} \\
(6.99)\end{array}$ & $\begin{array}{l}1.022^{* * *} \\
(6.84)\end{array}$ & $\begin{array}{l}0.978^{* * * *} \\
(6.55)\end{array}$ & $\begin{array}{l}0.973^{* * * *} \\
(6.45)\end{array}$ \\
\hline Firm leverage & & & & & $\begin{array}{l}0.035 \\
(0.39)\end{array}$ & $\begin{array}{l}0.218^{* * *} \\
(2.34)\end{array}$ & $\begin{array}{l}0.213^{* *} \\
(2.29)\end{array}$ & $\begin{array}{l}0.265^{* * * *} \\
(2.94)\end{array}$ \\
\hline Firm profitability & & & & & & $\begin{array}{l}0.951^{* * * *} \\
(7.01)\end{array}$ & $\begin{array}{l}0.944^{* * * *} \\
(6.95)\end{array}$ & $\begin{array}{l}0.968^{* * *} \\
(7.33)\end{array}$ \\
\hline Level 1 ADR & & & & & & & $\begin{array}{l}-0.029 \\
(0.27)\end{array}$ & \\
\hline Level 2 ADR & & & & & & & $\begin{array}{l}0.256^{* * * *} \\
(2.79)\end{array}$ & \\
\hline Level 3 ADR & & & & & & & $\begin{array}{l}-0.065 \\
(0.59)\end{array}$ & \\
\hline Rule 144a/Reg S ADR & & & & & & & $\begin{array}{l}-0.369^{* * *} \\
(3.38)\end{array}$ & \\
\hline Country fund & & & & & & & & $\begin{array}{l}0.928^{* * *} \\
(13.96)\end{array}$ \\
\hline Time dummies & Yes & Yes & Yes & Yes & Yes & Yes & Yes & Yes \\
\hline \# Obs & 9992 & 9992 & 9992 & 9992 & 9992 & 9992 & 9992 & 9992 \\
\hline \multirow[t]{3}{*}{$R$-squared } & 0.039 & 0.031 & 0.010 & 0.010 & 0.010 & 0.013 & 0.013 & 0.010 \\
\hline & \multicolumn{8}{|c|}{ Degree-open factor } \\
\hline & $(1)$ & $(2)$ & (3) & $(4)$ & $(5)$ & (6) & (7) & $(8)$ \\
\hline Degree-open & $\begin{array}{l}0.162^{* * * *} \\
(3.98)\end{array}$ & $\begin{array}{l}0.165^{* * * *} \\
(4.03)\end{array}$ & $\begin{array}{l}0.177^{* * * *} \\
(4.37)\end{array}$ & $\begin{array}{l}0.184^{* * * *} \\
(4.57)\end{array}$ & $\begin{array}{l}0.185^{* * *} \\
(4.58)\end{array}$ & $\begin{array}{l}0.173^{* * * *} \\
(4.29)\end{array}$ & $\begin{array}{l}0.179^{* * * *} \\
(4.42)\end{array}$ & $\begin{array}{l}0.139^{* * *} \\
(3.48)\end{array}$ \\
\hline Time Dummies & Yes & Yes & Yes & Yes & Yes & Yes & Yes & Yes \\
\hline Controls & Included & Included & Included & Included & Included & Included & Included & Included \\
\hline \# Obs & 9992 & 9992 & 9992 & 9992 & 9992 & 9992 & 9992 & 9992 \\
\hline R-Squared & 0.041 & 0.033 & 0.001 & 0.010 & 0.010 & 0.014 & 0.014 & 0.010 \\
\hline
\end{tabular}

The table reports coefficient estimates from firm-fixed effects regressions with $t$-statistics (absolute value), adjusted for firmlevel clustering, in parentheses. The dependent variable is Tobin's $q$. Openness to foreign investors is measured using either investable dummies or degree-open factors. Investable is a dummy variable that is set equal to one in years in which the firm is designated as investable., zero otherwise. The degree-open factor ranges from zero (not open to foreign investors) to one (fully open to foreign investors). Firm size is measured as the log of annual sales in real \$U.S. Firm growth is measured as the (geometric) average real growth in sales over the prior two years. Global Industry $Q$ is calculated as the average $Q$ of all global firms within each industry classification. Firm leverage is total debt to total assets, and profitability is defined as earnings before interest and taxation (EBIT) to total assets. ADR variables are dummy variables that are set equal to one in years in which the firm has an ADR of the specified type. Country fund is a dummy variable indicating the existence of a closed-end country fund in the firm's country. Also estimated but not reported are a full set of year dummies. Statistical significance is denoted by ${ }^{* * *}$, ${ }^{* *},{ }^{*}$ for the $1 \%, 5$, and $10 \%$ levels, respectively.

\subsection{Regression estimates}

In line with Mitton and O'Connor (2011), I first try to establish a causal link between investability and firm value. The results are outlined in Table 2. In subsequent analysis, I attempt to uncover whether it is better-governed firms that enjoy the largest valuation gains from becoming investable.

To do the former, I estimate a series of firm-fixed effects regressions of the following form:

$$
\text { Tobin's } q_{\mathrm{it}}=\alpha+\beta X_{\mathrm{it}}+\text { Investable }_{\mathrm{it}}+\text { Year }_{\mathrm{t}}+\text { Firm }_{\mathrm{i}}+\varepsilon_{\mathrm{it}}
$$


where Tobin's $q_{\text {it }}$ is Tobin's $q$ for firm i in year t, $X_{\text {it }}$ is a set of firm and industry controls (sales growth, size, global industry $q$, leverage and profitability), and Investable are 0/1 dummies. Year and Firm $_{\mathrm{i}}$ represent a full set of year and firm fixed-effects. The coefficient estimates are outlined in Table 2, with $t$-statistics calculated using standard errors adjusted for firm-level clustering reported in square brackets underneath (Petersen, 2009). ${ }^{10}$

In Column 1 of Table 2, I regress Tobin's $q$ on the investable dummies alone (time and fixed effects are included). In subsequent columns, I sequentially add firm and industry-level control variables. Column 6 presents the coefficient estimates with all firm and industry-level control variables included. In the remaining columns of Table 2, I control for indirect investability. In column 7, I add cross-listing dummy variables to column 6 . In column 8 , country fund data is added to the specification in column 6. The coefficient estimates on the investable dummies are positive and statistically significant in all regressions. The coefficient estimates range from 0.101 to 0.139 . Since the median investable firm has a Tobin's $q$ of 1.20 , this suggests that the act of becoming fully investable causes an average change in value of $10.5 \%$ (i.e., $(0.126 / 1.20)^{*} 100$ ) for the median firm. Also, the control variables tend to be of the correct sign and are statistically significant. Firm value increases with leverage, profitability, firm and industry growth, while smaller firms tend to be worth more. ${ }^{11}$ I document a cross-listing premium for Level 2 firms, but none for Level 3 capital-raising firms. Finally, country-fund availability impacts positively on firm value. In the remaining rows of Table 2, I re-estimate Eq. (1), but now, I measure openness to foreign investment using degree-open factors, a continuous variable ranging from zero (not open to foreign investors) to one (fully open to foreign investors). The coefficient estimates using the degree-open factors only serve to reinforce the findings just presented. Again, in all specifications, the coefficient estimates on the degree-open factors are positive and always statistically significant. These findings confirm the findings of Mitton and O'Connor (2011).

Tables 3-6 examine how the valuation gains, documented in Table 2, differ by level of corporate governance. In Table 3, I examine how the valuation gains from investability differ for single and dual-class investable firms. To do so, I estimate four different regression specifications, to account for the fact that the dual-class share indicator is time-invariant. In this instance, I can no longer estimate firm-fixed effects regressions (if I also want to include the dual-class dummy variable), since the fixed effects estimator uses a within-transformation, which would eliminate all time-invariant variables. ${ }^{12}$ In its place, I estimate pooled ordinary least squares estimates (POLS), random effects panel regressions (RE), a Chamberlain (1984) type model, which specifies the unobserved heterogeneity as a function of the firm-level means of the included (time-variant) regressors, as specified by Mundlak (1978), and finally, the fixed effects vector decomposition (FEVD) regression approach of Plumper and Troeger $(2007,2011) .{ }^{13}$ Amongst others, the benefit of using all four is that they allow me to include the dualclass (time-invariant) indicator. However, there are potential shortcomings in using each approach. For example, the pooled ordinary least squares estimates are likely to suffer from an omitted variable bias (unobserved heterogeneity) and be inconsistent. It is hard to envisage instances in which firm value is not affected by unobserved heterogeneity/attributes such as entrepreneurial skills/managerial ability, and access to valuable networks. The random effects approach overcomes this shortcoming to a point. The random effects approach accounts for the unobserved heterogeneity, but assumes that it is uncorrelated with other right-hand side (observable) variables. However, the results from a

\footnotetext{
${ }^{10}$ In unreported analysis, I show that the average and median investable firms is worth more than comparable non-investable firms in all but two years from 1988 to 2000. Interestingly, in the latter years of the sample period, dual-class share investable firms tend to be worth more single-class share. In event time (see Fig. 1), both single- and dual-class investable firms tend to be worth more than non-investable firms in the years immediately prior and subsequent to the investable year. The valuation premia disappear on the fifth year of becoming investable. However, the summary statistics suggest that they manifest again after five years of becoming investable. O'Connor (2010) does in fact show that "nvestable premia" does reappear once firms have been investable for at least five years, and in turn, he shows that "investable premia" are permanent. These summary findings are available from me upon request.

${ }^{11}$ Leverage tends to be value enhancing when managerial agency costs are severe (Harvey et al., 2004).

12 In subsequent analysis, I do estimate a series of separate fixed-effects regressions for single- and dual-class investable firms alone.

13 Others that use the fixed effects vector decomposition approach include Lensink and van der Molen (2010) and Davies et al. (2008).
} 

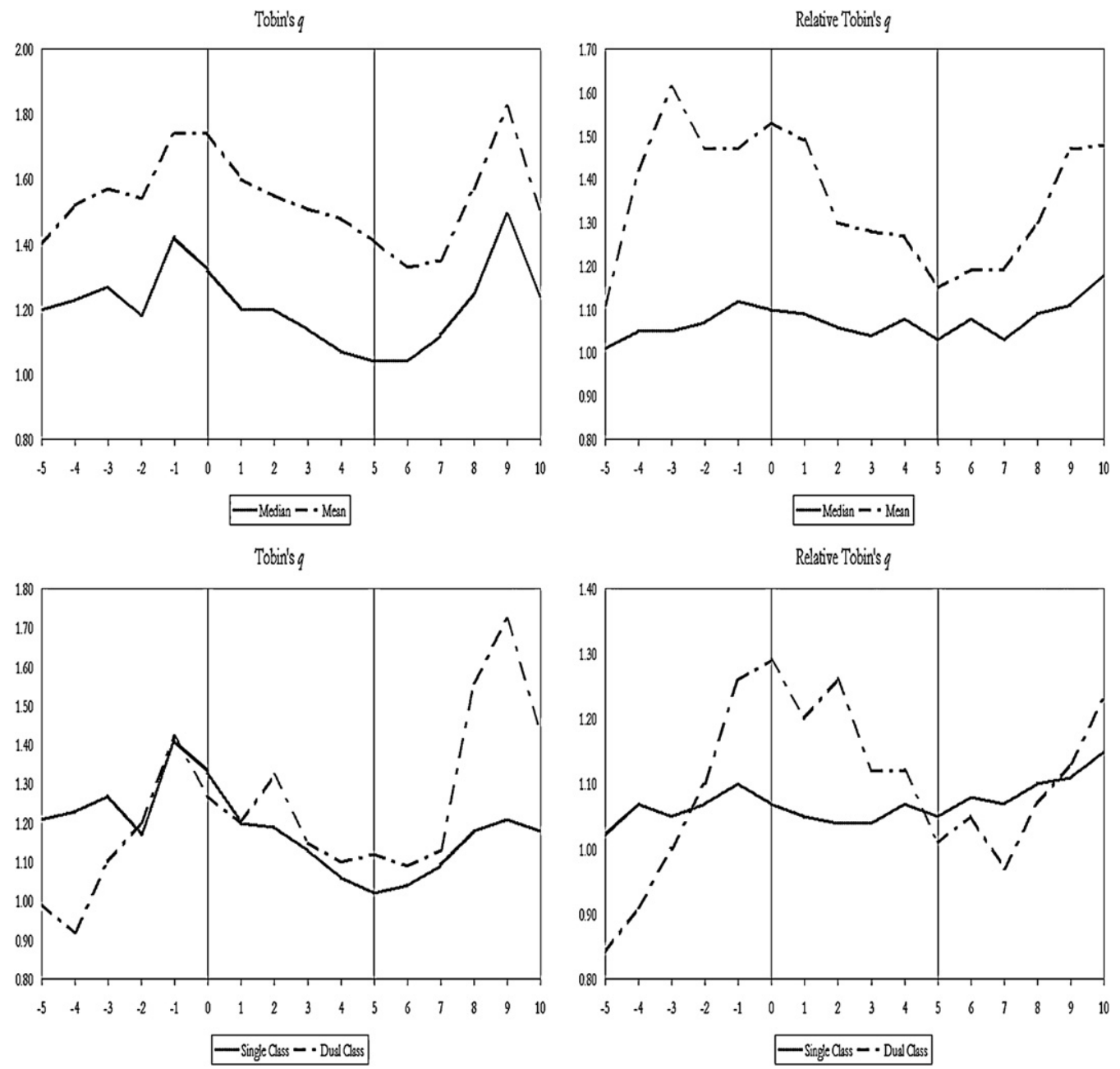

Fig. 1. This figure displays the mean and median value of investable firms from 5 years prior to becoming investable to 10 years after. The top row displays the mean and median absolute and relative value of investable firms. Absolute value is measured using Tobin's $q$. Tobin's $q$ is calculated as the book value of debt plus market capitalization divided by the book value of assets. Market value of debt is proxied using its book value counterpart, and the replacement cost of assets as the book value of assets. Book value of debt is calculated as the book value of total assets less the book value of equity. Relative value is measured using median-adjusted Relative $q$. Median-adjusted relative Tobin's $q$ is calculated as the value of each investable firm divided by the median value of all non-investable firms in each firm's home country (in each year). The bottom row displays the absolute and relative value of single- and dual-class share investable firms.

standard Hausman test suggest that this is not the case. Given the shortcomings of these approaches, I estimate a series of separate firm fixed-effects regressions for single- and dual-class share investable firms (and all non-investable firms) in Table 4, and for single- and dual-class share investable firms relative to other single- and dual-class non-investable firms in Table 5. The final approach, advocated by Plumper and Troeger $(2007,2011)$ is the fixed effects vector decomposition estimator. This approach decomposes the firm specific fixed effects $\left(\mathrm{Firm}_{\mathrm{i}}\right)$ into an unexplained part and a part explained by the time-invariant variables. It is estimated in three distinct steps. In the first step, the (firm) fixed effects are retrieved from a fixed-effects regression:

$$
\text { Tobin's } q_{\text {it }}=\alpha+\beta X_{\text {it }}+\text { Year }_{\mathrm{t}}+\text { Firm }_{\mathrm{i}}+\varepsilon_{\mathrm{it}}
$$


Table 3

Regression estimates of the effect of investability and on firm value.

\begin{tabular}{|c|c|c|c|c|c|c|c|c|}
\hline & \multicolumn{2}{|c|}{$\begin{array}{l}\text { Pooled ordinary least } \\
\text { squares (POLS) }\end{array}$} & \multicolumn{2}{|c|}{ Random effects (RE) } & \multicolumn{2}{|c|}{ Mundlak (1978) } & \multicolumn{2}{|c|}{$\begin{array}{l}\text { Fixed effects vector } \\
\text { decomposition (FEVD }\end{array}$} \\
\hline & (1) & (2) & (3) & (4) & (5) & (6) & $(7)$ & (8) \\
\hline Degree-open & $\begin{array}{l}0.218^{* *} \\
(2.55)\end{array}$ & & $\begin{array}{l}0.189^{* * *} \\
(4.73)\end{array}$ & & $\begin{array}{l}0.115^{*} \\
(1.69)\end{array}$ & & $\begin{array}{l}0.177^{* * *} \\
(6.72)\end{array}$ & \\
\hline $\begin{array}{l}\text { Degree-open } \times \text { dual- } \\
\text { class }\end{array}$ & $\begin{array}{l}-0.056 \\
(0.47)\end{array}$ & & $\begin{array}{l}-0.031 \\
(0.41)\end{array}$ & & $\begin{array}{l}-0.075 \\
(0.65)\end{array}$ & & $\begin{array}{l}-0.018 \\
(0.31)\end{array}$ & \\
\hline Investable & & $\begin{array}{l}0.208^{* * *} \\
(3.24)\end{array}$ & & $\begin{array}{l}0.161^{* * *} \\
(4.67)\end{array}$ & & $\begin{array}{l}0.072 \\
(1.26)\end{array}$ & & $\begin{array}{l}0.129^{* * *} \\
(6.26)\end{array}$ \\
\hline Investable $\times$ dual-class & & $\begin{array}{l}-0.076 \\
(0.76)\end{array}$ & & $\begin{array}{l}-0.039 \\
(0.57)\end{array}$ & & $\begin{array}{l}-0.084 \\
(0.87)\end{array}$ & & $\begin{array}{l}-0.017 \\
(0.35)\end{array}$ \\
\hline Dual-class & $\begin{array}{l}-0.182^{* * *} \\
(2.71)\end{array}$ & $\begin{array}{l}-0.173^{* * *} \\
(2.58)\end{array}$ & $\begin{array}{l}-0.263^{* * *} \\
(4.06)\end{array}$ & $\begin{array}{l}-0.258^{* * *} \\
(3.99)\end{array}$ & $\begin{array}{l}-0.195^{* * *} \\
(2.88)\end{array}$ & $\begin{array}{l}-0.185^{* * *} \\
(2.73)\end{array}$ & $\begin{array}{l}-0.179^{* * *} \\
(18.78)\end{array}$ & $\begin{array}{l}-0.176^{* * *} \\
(19.96)\end{array}$ \\
\hline Firm size & $\begin{array}{l}-0.019 \\
(1.10)\end{array}$ & $\begin{array}{l}-0.024 \\
(1.33)\end{array}$ & $\begin{array}{l}-0.043^{* * *} \\
(4.10)\end{array}$ & $\begin{array}{l}-0.045^{* * *} \\
(4.23)\end{array}$ & $\begin{array}{l}-0.070^{*} \\
(1.86)\end{array}$ & $\begin{array}{l}-0.069 * \\
(1.83)\end{array}$ & $\begin{array}{l}-0.079^{* * *} \\
(18.14)\end{array}$ & $\begin{array}{l}-0.079^{* * *} \\
(17.72)\end{array}$ \\
\hline Firm growth & $\begin{array}{l}0.591^{* * *} \\
(4.39)\end{array}$ & $\begin{array}{l}0.603^{* * *} \\
(4.46)\end{array}$ & $\begin{array}{l}0.647^{* * *} \\
(7.97)\end{array}$ & $\begin{array}{l}0.650^{* * *} \\
(7.99)\end{array}$ & $\begin{array}{l}0.796^{* * *} \\
(6.02)\end{array}$ & $\begin{array}{l}0.798^{* * *} \\
(6.04)\end{array}$ & $\begin{array}{l}0.698^{* * *} \\
(8.78)\end{array}$ & $\begin{array}{l}0.696^{* * *} \\
(8.75)\end{array}$ \\
\hline Global industry $Q$ & $\begin{array}{l}1.057^{* * *} \\
(5.82)\end{array}$ & $\begin{array}{l}1.031^{* * *} \\
(5.63)\end{array}$ & $\begin{array}{l}1.082^{* * *} \\
(6.90)\end{array}$ & $\begin{array}{l}1.069^{* * *} \\
(6.82)\end{array}$ & $\begin{array}{l}1.044^{* * *} \\
(5.66)\end{array}$ & $\begin{array}{l}1.010^{* * *} \\
(5.43)\end{array}$ & $\begin{array}{l}1.034^{* * *} \\
(10.82)\end{array}$ & $\begin{array}{l}1.022^{* * *} \\
(10.57)\end{array}$ \\
\hline Firm leverage & $\begin{array}{l}-0.032 \\
(0.31)\end{array}$ & $\begin{array}{l}-0.038 \\
(0.37)\end{array}$ & $\begin{array}{l}0.085 \\
(1.47)\end{array}$ & $\begin{array}{l}0.078 \\
(1.34)\end{array}$ & $\begin{array}{l}0.182 \\
(1.22)\end{array}$ & $\begin{array}{l}0.176 \\
(1.18)\end{array}$ & $\begin{array}{l}0.226^{* * * *} \\
(4.74)\end{array}$ & $\begin{array}{l}0.218^{* * * *} \\
(4.57)\end{array}$ \\
\hline Firm profitability & $\begin{array}{l}1.912^{* * *} \\
(7.72)\end{array}$ & $\begin{array}{l}1.912^{* * *} \\
(7.71)\end{array}$ & $\begin{array}{l}1.150^{* * *} \\
(12.09)\end{array}$ & $\begin{array}{l}1.153^{* * *} \\
(12.12)\end{array}$ & $\begin{array}{l}1.027^{* * * *} \\
(5.67)\end{array}$ & $\begin{array}{l}1.031^{* * * *} \\
(5.68)\end{array}$ & $\begin{array}{l}0.948^{* * *} \\
(8.77)\end{array}$ & $\begin{array}{l}0.952^{* * *} \\
(8.77)\end{array}$ \\
\hline Time dummies & Yes & Yes & Yes & Yes & Yes & Yes & Yes & Yes \\
\hline Country dummies & Yes & Yes & Yes & Yes & Yes & Yes & Yes & Yes \\
\hline \# Obs & 9992 & 9992 & 9992 & 9992 & 9992 & 9992 & 9992 & 9992 \\
\hline$R$-squared & 0.206 & 0.206 & 0.193 & 0.193 & 0.219 & 0.220 & 0.603 & 0.602 \\
\hline
\end{tabular}

The table reports coefficient estimates from a series of regressions which estimate the effect of openness to foreign investment and agency costs on firm value. Columns 1 and 2 reports coefficient estimates from pooled ordinary least squares estimates (POLS) with $t$-stats calculated using standard errors clustered by firm presented underneath in brackets. Columns 3 and 4 reports coefficient estimates from random effects regressios. Columns 5 and 6 do likewise using Mundlak (1978) correction terms to account for unobserved heterogeneity. Columns 7 and 8 report coefficient estimates from Fixed Effects Vector Decomposition (FEVD) regressions. The dependent variable is Tobin's $q$. The degree-open factor ranges from zero (not open to foreign investors) to one (fully open to foreign investors). Dual-Class is 1 if the firm is a dual-class firm, 0 otherwise. Firm size is measured as the $\log$ of annual sales in real \$U.S. Firm growth is measured as the (geometric) average real growth in sales over the prior two years. Global Industry $Q$ is calculated as the average $Q$ of all global firms within each industry classification. Firm leverage is total debt to total assets, and profitability is defined as earnings before interest and taxation (EBIT) to total assets. Also estimated but not reported are a constant, a full set of year dummies, and a full set of country dummies (In specifications 1-6). Statistical significance is denoted by ${ }^{* * *},{ }^{* *},{ }^{*}$ for the $1 \%, 5$, and $10 \%$ levels, respectively.

Second, an ordinary least squares regression of the fixed effects on the time-invariant variables is performed:

$$
\text { Firm }_{\mathrm{i}}=v+\beta \text { Dual }- \text { Class }_{\mathrm{i}}+\varepsilon_{2 \mathrm{i}}
$$

The final step, estimated using pooled ordinary least squares includes all time-variant and invariant variables plus the error term from the second stage regression: ${ }^{14}$

$$
\begin{aligned}
\text { Tobin's } q_{\mathrm{it}}= & \alpha+\beta_{1} X_{\mathrm{it}}+\beta_{2} \text { Investable }_{\mathrm{it}}+\beta_{3} \text { Investable }_{\mathrm{it}} * \text { Dual }_{- \text {Class }_{\mathrm{i}}}+\beta_{4} \text { Dual } \text { Class }_{\mathrm{i}} \\
& + \text { Year }_{\mathrm{t}}+\text { Country }_{\mathrm{c}}+\varepsilon_{2 \mathrm{i}}+\varepsilon_{\mathrm{it}}
\end{aligned}
$$

\footnotetext{
14 I follow Lensink and van der Molen (2010) by including time fixed effects (year dummies) in both the first and third steps of the FEVD regressions. Also, I find that the coefficient estimates from the fixed effects vector decomposition regressions are qualitatively unchanged when I exclude country fixed-effects from stage 3 (Eq. (4)).
} 
Table 4

Regression estimates of the effect of investability on firm value for single- and dual-class share firms.

\begin{tabular}{|c|c|c|c|c|c|c|c|c|}
\hline & \multicolumn{8}{|c|}{ Investable dummies } \\
\hline & \multicolumn{4}{|c|}{$\begin{array}{l}\text { Single-class share investable firms and } \\
\text { all non-investable firms }\end{array}$} & \multicolumn{4}{|c|}{$\begin{array}{l}\text { Dual-class share investable firms and } \\
\text { all non-investable firms }\end{array}$} \\
\hline & $(1)$ & (2) & (3) & (4) & (5) & (6) & (7) & (8) \\
\hline Investable & $\begin{array}{l}0.127^{* *} \\
(2.20)\end{array}$ & $\begin{array}{l}0.145^{* * *} \\
(2.68)\end{array}$ & $\begin{array}{l}0.161^{* * *} \\
(3.00)\end{array}$ & $\begin{array}{l}0.104^{* *} \\
(1.97)\end{array}$ & $\begin{array}{l}0.134 \\
(1.16)\end{array}$ & $\begin{array}{l}0.120 \\
(1.07)\end{array}$ & $\begin{array}{l}0.131 \\
(1.22)\end{array}$ & $\begin{array}{l}0.144 \\
(1.32)\end{array}$ \\
\hline Firm size & & $\begin{array}{l}-0.079^{*} \\
(1.89)\end{array}$ & $\begin{array}{l}-0.077^{*} \\
(1.86)\end{array}$ & $\begin{array}{l}-0.083^{* *} \\
(2.17)\end{array}$ & & $\begin{array}{l}-0.065 \\
(1.54)\end{array}$ & $\begin{array}{l}-0.064 \\
(1.51)\end{array}$ & $\begin{array}{l}-0.106^{* * *} \\
(2.75)\end{array}$ \\
\hline Firm Growth & & $\begin{array}{l}0.664^{* * * *} \\
(4.82)\end{array}$ & $\begin{array}{l}0.657^{* * *} \\
(4.81)\end{array}$ & $\begin{array}{l}0.562^{* * *} \\
(4.21)\end{array}$ & & $\begin{array}{l}0.562^{* * * *} \\
(3.87)\end{array}$ & $\begin{array}{l}0.559^{* * * *} \\
(3.85)\end{array}$ & $\begin{array}{l}0.533^{* * * *} \\
(3.80)\end{array}$ \\
\hline Global industry $Q$ & & $\begin{array}{l}0.975^{* * * *} \\
(4.51)\end{array}$ & $\begin{array}{l}0.967^{* * * *} \\
(4.48)\end{array}$ & $\begin{array}{l}0.866^{* * *} \\
(4.22)\end{array}$ & & $\begin{array}{l}1.240^{* * * *} \\
(5.57)\end{array}$ & $\begin{array}{l}1.200^{* * *} \\
(5.28)\end{array}$ & $\begin{array}{l}1.133^{* * * *} \\
(4.82)\end{array}$ \\
\hline Firm leverage & & $\begin{array}{l}0.255^{*} \\
(1.72)\end{array}$ & $\begin{array}{l}0.247^{*} \\
(1.66)\end{array}$ & $\begin{array}{l}0.297^{* *} \\
(2.12)\end{array}$ & & $\begin{array}{l}0.293^{*} \\
(1.74)\end{array}$ & $\begin{array}{l}0.293^{*} \\
(1.74)\end{array}$ & $\begin{array}{l}0.356^{* *} \\
(2.22)\end{array}$ \\
\hline Firm profitability & & $\begin{array}{l}0.907^{* * * *} \\
(4.79)\end{array}$ & $\begin{array}{l}0.894^{* * *} \\
(4.73)\end{array}$ & $\begin{array}{l}0.920^{* * *} \\
(5.04)\end{array}$ & & $\begin{array}{l}0.833^{* * * *} \\
(4.37)\end{array}$ & $\begin{array}{l}0.829 * * * \\
(4.37)\end{array}$ & $\begin{array}{l}0.856^{* * *} \\
(4.68)\end{array}$ \\
\hline Level 1 ADR & & & $\begin{array}{l}-0.105 \\
(0.51)\end{array}$ & & & & $\begin{array}{l}0.084 \\
(0.36)\end{array}$ & \\
\hline Level 2 ADR & & & $\begin{array}{l}0.281^{* * *} \\
(2.67)\end{array}$ & & & & $\begin{array}{l}0.260^{*} \\
(1.68)\end{array}$ & \\
\hline Level 3 ADR & & & $\begin{array}{l}-0.066 \\
(0.48)\end{array}$ & & & & & \\
\hline Rule 144a/Reg S ADR & & & $\begin{array}{l}-0.365^{* *} \\
(2.21)\end{array}$ & & & & $\begin{array}{l}-0.412 \\
(1.41)\end{array}$ & \\
\hline Country Fund & & & & $\begin{array}{l}0.947^{* * *} \\
(8.92)\end{array}$ & & & & $\begin{array}{l}1.076^{* * *} \\
(9.57)\end{array}$ \\
\hline Time dummies & Yes & Yes & Yes & Yes & Yes & Yes & Yes & Yes \\
\hline \# Obs & 9523 & 9523 & 9523 & 9523 & 8100 & 8100 & 8100 & 8100 \\
\hline \multirow[t]{4}{*}{$R$-squared } & 0.038 & 0.010 & 0.010 & 0.010 & 0.034 & 0.015 & 0.016 & 0.010 \\
\hline & \multicolumn{8}{|c|}{ Degree-open factor } \\
\hline & \multicolumn{4}{|c|}{$\begin{array}{l}\text { Single-class share investable firms and } \\
\text { all non-investable firms }\end{array}$} & \multicolumn{4}{|c|}{$\begin{array}{l}\text { Dual-class share investable firms and } \\
\text { all non-investable firms }\end{array}$} \\
\hline & (1) & $(2)$ & (3) & (4) & $(5)$ & (6) & (7) & (8) \\
\hline Degree-open & $\begin{array}{l}0.165^{* *} \\
(2.48)\end{array}$ & $\begin{array}{l}0.186^{* * *} \\
(2.94)\end{array}$ & $\begin{array}{l}0.191^{* * *} \\
(2.99)\end{array}$ & $\begin{array}{l}0.140^{* *} \\
(2.23)\end{array}$ & $\begin{array}{l}0.104 \\
(0.79)\end{array}$ & $\begin{array}{l}0.084 \\
(0.65)\end{array}$ & $\begin{array}{l}0.090 \\
(0.72)\end{array}$ & $\begin{array}{l}0.077 \\
(0.62)\end{array}$ \\
\hline Time dummies & Yes & Yes & Yes & Yes & Yes & Yes & Yes & Yes \\
\hline Controls & Included & Included & Included & Included & Included & Included & Included & Included \\
\hline \# Obs & 9523 & 9523 & 9523 & 9523 & 8100 & 8100 & 8100 & 8100 \\
\hline$R$-squared & 0.039 & 0.010 & 0.011 & 0.010 & 0.034 & 0.015 & 0.016 & 0.010 \\
\hline
\end{tabular}

The table reports coefficient estimates from firm-fixed effects regressions with $t$-statistics (absolute value), adjusted for firmlevel clustering, in parentheses. Seperate regressions are performed for single- and dual-class investable firms. The dependent variable is Tobin's $q$. Openness to foreign investors is measured using either investable dummies or degree-open factors. Investable is a dummy variable that is set equal to one in years in which the firm is designated as investable., zero otherwise. The degree open factor ranges from zero (not open to foreign investors) to one (fully open to foreign investors). Firm size is measured as the log of annual sales in real \$U.S. Firm growth is measured as the (geometric) average real growth in sales over the prior two years. Global Industry $Q$ is calculated as the average $Q$ of all global firms within each industry classification. Firm leverage is total debt to total assets, and profitability is defined as ernings before interest and taxation (EBIT) to total assets. ADR variables are dummy variables that are set equal to one in years in which the firm has an ADR of the specified type. Country fund is a dummy variable indicating the existence of a closed-end country fund in the firm's country. Also estimated but not reported is a constant and a full set of year dummies. Statistical significance is denoted by ***, **, * for the $1 \%, 5$, and $10 \%$ levels, respectively. 
Table 5

Regression estimates of the effect of investability on firm value.

\begin{tabular}{|c|c|c|c|c|}
\hline & \multicolumn{4}{|c|}{ Fixed effects (FE) } \\
\hline & \multicolumn{2}{|c|}{ Single-class share firms only } & \multicolumn{2}{|c|}{ Dual-class share firms only } \\
\hline & $(1)$ & $(2)$ & (3) & $(4)$ \\
\hline Degree-open & $\begin{array}{l}0.171^{* * * *} \\
(2.91)\end{array}$ & & $\begin{array}{l}0.286^{*} \\
(1.89)\end{array}$ & \\
\hline Investable & & $\begin{array}{l}0.122^{* *} \\
(2.44)\end{array}$ & & $\begin{array}{l}0.257^{*} \\
(1.83)\end{array}$ \\
\hline Firm size & $\begin{array}{l}-0.135^{* * *} \\
(3.64)\end{array}$ & $\begin{array}{l}-0.135^{* * *} \\
(3.61)\end{array}$ & $\begin{array}{l}0.010 \\
(0.09)\end{array}$ & $\begin{array}{l}0.010 \\
(0.10)\end{array}$ \\
\hline Firm growth & $\begin{array}{l}0.842^{* * * *} \\
(5.56)\end{array}$ & $\begin{array}{l}0.842^{* * * *} \\
(5.54)\end{array}$ & $\begin{array}{l}0.412^{* *} \\
(2.07)\end{array}$ & $\begin{array}{l}0.406^{* *} \\
(2.03)\end{array}$ \\
\hline Global industry $Q$ & $\begin{array}{l}0.986^{* * *} \\
(4.42)\end{array}$ & $\begin{array}{l}0.969^{* * *} \\
(4.33)\end{array}$ & $\begin{array}{l}1.074^{* * *} \\
(2.84)\end{array}$ & $\begin{array}{l}1.067^{* * *} \\
(2.81)\end{array}$ \\
\hline Firm leverage & $\begin{array}{l}0.100 \\
(0.66)\end{array}$ & $\begin{array}{l}0.086 \\
(0.58)\end{array}$ & $\begin{array}{l}0.329 \\
(1.28)\end{array}$ & $\begin{array}{l}0.327 \\
(1.28)\end{array}$ \\
\hline Firm profitability & $\begin{array}{l}1.021^{* * * *} \\
(4.70)\end{array}$ & $\begin{array}{l}1.024^{* * * *} \\
(4.68)\end{array}$ & $\begin{array}{l}0.800^{* * *} \\
(2.90)\end{array}$ & $\begin{array}{l}0.807^{* * *} \\
(2.93)\end{array}$ \\
\hline Time dummies & Yes & Yes & Yes & Yes \\
\hline \# Obs & 7091 & 7091 & 2901 & 2901 \\
\hline$R$-squared & 0.001 & 0.001 & 0.118 & 0.115 \\
\hline
\end{tabular}

The table reports coefficient estimates from a series of regressions which estimate the effect of openness to foreign investment on firm value. I report coefficient estimates from firm-fixed effects regressions with $t$-statistics (absolute value), adjusted for firm-level clustering, in parentheses. Seperate regressions are performed for dual- and single-class firms (investable and noninvestable), respectively. The dependent variable is Tobin's $q$. The degree-open factor ranges from zero (not open to foreign investors) to one (fully open to foreign investors). Also estimated but not reported are a constant, a full set of year dummies. Statistical significance is denoted by ${ }^{* * *},{ }^{* *},{ }^{*}$ for the $1 \%, 5$, and $10 \%$ levels, respectively.

In summary, Table 3 contains coefficient estimates from the following four regression specifications:

$$
\begin{aligned}
\text { Tobin's } q_{\mathrm{it}}= & \alpha+\beta_{1} X_{\mathrm{it}}+\beta_{2} \text { Investable }_{\mathrm{it}}+\beta_{3} \text { Investable }_{\mathrm{it}} * \text { Dual }_{- \text {Class }_{\mathrm{i}}}+\beta_{4} \text { Dual }- \text { Class }_{\mathrm{i}} \\
& + \text { Year }_{\mathrm{t}}+\text { Country }_{\mathrm{c}}+\varepsilon_{\mathrm{it}} \text { POLS }
\end{aligned}
$$

Tobin's $q_{\mathrm{it}}=\alpha+\beta_{1} X_{\mathrm{it}}+\beta_{2}$ Investable $_{\mathrm{it}}+\beta_{3}$ Investable $_{\mathrm{it}} *$ Dual - Class $_{\mathrm{i}}+\beta_{4}$ Dual - Class $_{\mathrm{i}}$

$$
+ \text { Year }_{\mathrm{t}}+\text { Firm }_{\mathrm{i}}+\text { Country }_{\mathrm{c}}+\varepsilon_{\mathrm{it}} \text { RE : }
$$

Tobin's $q_{\mathrm{it}}=\alpha+\beta_{1} X_{\mathrm{it}}+\beta_{2}$ Investable $_{\mathrm{it}}+\beta_{3}$ Investable $_{\mathrm{it}} *$ Dual - Class $_{\mathrm{i}}+\beta_{4}$ Dual - Class $_{\mathrm{i}}$

$$
+ \text { Year }_{\mathrm{t}}+\text { Mundlak }_{\mathrm{i}}+\text { Country }_{\mathrm{c}}+\varepsilon_{\mathrm{it}} \text { Mundlak : }
$$

Tobin's $q_{\text {it }}=\alpha+\beta_{1} X_{\mathrm{it}}+\beta_{2}$ Investable $_{\mathrm{it}}+\beta_{3}$ Investable $_{\mathrm{it}} *$ Dual - Class $_{\mathrm{i}}+\beta_{4}$ Dual - Class $_{\mathrm{i}}$

$$
+ \text { Year }_{\mathrm{t}}+\text { Country }_{\mathrm{c}}+\varepsilon_{2 \mathrm{i}}+\varepsilon_{\mathrm{it}} \text { FEVD : }
$$

In these regression specifications, the coefficient estimate $\left(\beta_{2}\right)$ captures the effect of investability on the value of single-class investable firms alone. The sum $\left(\beta_{2}+\beta_{3}\right)$ of the sole investable (degreeopen) dummy $\left(\beta_{2}\right)$ and the interaction of the investable (degree-open) dummy with the dual-class indicator $\left(\beta_{3}\right)$ capture the effect of investability on the value of dual-class firms. Thus, the coefficient on the interaction term tells us how dual-class share firms perform relative to single-class share firms when both become investable. A priori, if single-class share firms reap larger valuation gains than dual-class firms, a priori, I would expect ( $\left.\beta_{2}\right)$ to be positive and statistically significant (as per Table 2 ), and $\left(\beta_{2}+\beta_{3}\right)$ to be less than $\left(\beta_{2}\right)$. If investability results in valuation gains for dual-class share firms, then $\left(\beta_{2}+\beta_{3}\right)$ should be positive. 
Table 6

Regression estimates of the effect of investability and agency costs on firm value.

\begin{tabular}{|c|c|c|c|c|c|c|}
\hline & \multicolumn{6}{|c|}{ Investable dummies } \\
\hline & \multicolumn{3}{|c|}{ Sales-to-assets (Agency Cost 1 ) } & \multicolumn{3}{|c|}{ Operating expenses-to-sales (Agency Cost 2) } \\
\hline & All & $\begin{array}{l}\text { Above } \\
\text { median AC } \\
1\end{array}$ & $\begin{array}{l}\text { Below } \\
\text { median AC } \\
1\end{array}$ & All & $\begin{array}{l}\text { Above } \\
\text { median AC } \\
2\end{array}$ & $\begin{array}{l}\text { Below } \\
\text { median AC } \\
2\end{array}$ \\
\hline Investable & $\begin{array}{l}0.125^{* * *} \\
(3.43)\end{array}$ & $\begin{array}{l}0.196^{* * *} \\
(2.84)\end{array}$ & $\begin{array}{l}0.086 \\
(1.38)\end{array}$ & $\begin{array}{l}0.125^{* * *} \\
(3.43)\end{array}$ & $\begin{array}{l}0.037 \\
(0.66)\end{array}$ & $\begin{array}{l}0.186^{* *} \\
(2.22)\end{array}$ \\
\hline Firm size & $\begin{array}{l}-0.074^{* * *} \\
(3.14)\end{array}$ & $\begin{array}{l}-0.126^{* *} \\
(2.23)\end{array}$ & $\begin{array}{l}-0.063 \\
(1.31)\end{array}$ & $\begin{array}{l}-0.074^{* * *} \\
(3.14)\end{array}$ & $\begin{array}{l}-0.081^{*} \\
(1.80)\end{array}$ & $\begin{array}{l}-0.029 \\
(0.36)\end{array}$ \\
\hline Firm growth & $\begin{array}{l}0.835^{* * *} \\
(8.28)\end{array}$ & $\begin{array}{l}0.850^{* * * *} \\
(3.19)\end{array}$ & $\begin{array}{l}0.586^{* * * *} \\
(3.62)\end{array}$ & $\begin{array}{l}0.835^{* * * *} \\
(8.28)\end{array}$ & $\begin{array}{l}0.487^{* * * *} \\
(2.90)\end{array}$ & $\begin{array}{l}0.918^{* * * *} \\
(4.39)\end{array}$ \\
\hline Global industry $Q$ & $\begin{array}{l}1.066^{* * *} \\
(6.99)\end{array}$ & $\begin{array}{l}1.522^{* * *} \\
(9.36)\end{array}$ & $\begin{array}{l}0.819^{* * * *} \\
(3.94)\end{array}$ & $\begin{array}{l}1.066^{* * *} \\
(6.99)\end{array}$ & $\begin{array}{l}0.776^{* * * *} \\
(3.34)\end{array}$ & $\begin{array}{l}1.292^{* * *} \\
(5.12)\end{array}$ \\
\hline Firm leverage & $\begin{array}{l}0.035 \\
(0.39)\end{array}$ & $\begin{array}{l}0.092 \\
(0.51)\end{array}$ & $\begin{array}{l}0.155 \\
(0.83)\end{array}$ & $\begin{array}{l}0.035 \\
(0.39)\end{array}$ & $\begin{array}{l}0.292 \\
(1.56)\end{array}$ & $\begin{array}{l}0.010 \\
(0.04)\end{array}$ \\
\hline Firm profitability & $\begin{array}{l}-0.074^{* * *} \\
(3.14)\end{array}$ & $\begin{array}{l}0.860^{\text {**** }} \\
(3.52)\end{array}$ & $\begin{array}{l}0.868^{* * *} \\
(3.50)\end{array}$ & $\begin{array}{l}-0.074^{* * *} \\
(3.14)\end{array}$ & $\begin{array}{l}0.306 \\
(1.51)\end{array}$ & $\begin{array}{l}1.967^{* * * *} \\
(4.52)\end{array}$ \\
\hline Time dummies & Yes & Yes & Yes & Yes & Yes & Yes \\
\hline \# Obs & 9992 & 3829 & 6163 & 9992 & 5911 & 4081 \\
\hline \multirow[t]{4}{*}{$R$-squared } & 0.013 & 0.010 & 0.029 & 0.013 & 0.010 & 0.133 \\
\hline & \multicolumn{6}{|c|}{ Degree-open factor } \\
\hline & \multicolumn{3}{|c|}{ Sales-to-assets (Agency Cost 1 ) } & \multicolumn{3}{|c|}{ Operating expenses-to-sales (Agency Cost 2 ) } \\
\hline & All & $\begin{array}{l}\text { Above } \\
\text { median AC } \\
1\end{array}$ & $\begin{array}{l}\text { Below } \\
\text { median AC } \\
1\end{array}$ & All & $\begin{array}{l}\text { Above } \\
\text { median AC } \\
2\end{array}$ & $\begin{array}{l}\text { Below } \\
\text { median AC } \\
2\end{array}$ \\
\hline Degree-open & $\begin{array}{l}0.185^{* * *} \\
(4.58)\end{array}$ & $\begin{array}{l}0.223^{* *} \\
(1.98)\end{array}$ & $\begin{array}{l}0.098 \\
(1.45)\end{array}$ & $\begin{array}{l}0.185^{* * *} \\
(4.58)\end{array}$ & $\begin{array}{l}0.026 \\
(0.38)\end{array}$ & $\begin{array}{l}0.246^{* * * *} \\
(2.74)\end{array}$ \\
\hline Time dummies & Yes & Yes & Yes & Yes & Yes & Yes \\
\hline Controls & Included & Included & Included & Included & Included & Included \\
\hline \# Obs & 9992 & 3829 & 6163 & 9992 & 5911 & 4081 \\
\hline$R$-squared & 0.010 & 0.010 & 0.029 & 0.010 & 0.010 & 0.130 \\
\hline
\end{tabular}

The table reports coefficient estimates from firm-fixed effects regressions for seperate regressions for firms that were and were not above the sample median agency costs, with $t$-statistics (absolute value), adjusted for firm-level clustering, in parentheses. The dependent variable is Tobin's $q$. Investable is a dummy variable that is set equal to one in years in which the firm is designated as investable., zero otherwise. Agency Costs is either sales to assets (Agency Cost 1) or operating expenses to sales (Agency Cost 2). Firm size is measured as the log of annual sales in real \$U.S. Firm growth is measured as the (geometric) average real growth in sales over the prior two years. Global Industry $Q$ is calculated as the average $Q$ of all global firms within each industry classification. Firm leverage is total debt to total assets, and profitability is defined as earnings before interest and taxation (EBIT) to total assets. Also estimated but not reported are a full set of year dummies. Statistical significance is denoted by ${ }^{* * *},{ }^{* *},{ }^{*}$ for the $1 \%, 5$, and $10 \%$ levels, respectively.

The coefficient estimates in Table 3 suggest that this is not the case. In line with the analysis presented in Table 2, the coefficient estimates on the sole investable (and degree-open factor) variable $\left(\beta_{2}\right)$ is always positive and statistically significant; single-class share firms do experience a large and statistically significant "investable premia". The coefficient estimates (using the investable dummies) range from 0.072 to a high of 0.208 , with an average coefficient estimate of 0.143 . Since the median single-class share investable firm has a Tobin's $q$ of 1.17 , this suggests that the act of becoming fully investable causes an average change in value of $12.22 \%$ for the median single-class share investable firm (i.e., $\left.(0.143 / 1.17)^{*} 100\right)$. Dual-class share investable firms appear to do just as well; the coefficient estimates on the interaction terms are negative (and small), and always statistically insignificant, suggesting that dual-class share firms do just as well as single-class firms once both become investable. For these firms, act of becoming investable causes an average change in value of $11 \%$ (i.e., $(0.143 / 1.30)^{*} 100$ ), almost identical to the change in value experienced by single-class share investable firms. 
Since these findings run contrary to my prior expectations, and given the potential concerns with the estimators employed in Table 3, I explore this issue further in Table 4. I now modify my original sample of firms in such a manner to allow me to estimate a series of firm fixed-effects regressions a la Mitton and O'Connor (2011). To do so, I create two distinct samples of firms. In the first, I retain all non-investable firms, and keep only single-class share investable firms. In the second, I again retain all non-investable firms, and keep only dual-class share investable firms. I then estimate Eq. (1) for both sub-samples of firms and using both measures of access to foreign ownership. ${ }^{15}$ If the results from Table 3 hold, I would then expect to find no significant difference in the coefficient estimates on the investable dummy for both single- and dual-class firms in the firm fixed-effects regressions. The coefficient estimates presented in Table 4 suggest otherwise.

In Table 4, I estimate a series of firm-fixed effects regressions, but now for single- and dual-class investable firms alone. The coefficient estimates for single-class investable firms are presented in columns 1 to 4 . The corresponding estimates for dual-class firms are presented in the remaining columns of Table 4 (5-8). The coefficient estimates suggest that only single-class share investable firms enjoy an "investable premium". For these firms, the coefficient estimates on both the investable and degree-open factors are positive and statistically significant, ranging from 0.104 to 0.161 ( 0.140 to a high of 0.191 using the degree-open factors), with an average coefficient estimate of $0.134(0.171$ using the degree-open factors). These coefficient estimates imply an average change in value of $11.45 \%$ (i.e., $\left.(0.134 / 1.17)^{*} 100\right)$ for single-class share firms.

In contrast to both the findings presented for single-class share firms and the results presented in Table 3, there is no "investable premium" for dual-class share firms. The coefficient estimates are positive on the investable and degree-open factors, but always statistically indifferent to zero. These results suggest that the "investable premium" is large and statistically significant for single-class share firms; for dual-class share firms, there is no premium. These findings are in line with my prior expectations, and are consistent with the view that better-governed firms should reap the largest gains from becoming investable. In this paper, I find that single-class share firms, typically better-governed than dual-class share firms do. Using the liberalization of the Korean equity market, Bae and Goyal (2010) find likewise.

Finally, the coefficient estimates on the control variables from Tables 3 and 4 are correctly signed and invariably statistically significant. In all specifications, dual-class share firms tend to be worth less than single-class share firms. This is in line with a large literature, which suggests that investors apply a larger discount rate to these firms (Lins, 2003; Durnev and Kim, 2005; Smart et al., 2008; Masulis et al., 2009). Finally, firm value tends to increase in firm and industry growth, leverage and profitability. Large firms tend to be valued less highly than smaller firms.

Table 4 suggests that only single-class share investable firms enjoy an "investable premium". Nonetheless, these findings do not rule out the possibility that dual-class share firms enjoy an "investable premium" when compared to other non-investable dual-class share firms. Table 4 suggests that when compared to single- and dual-class non-investable firms, dual-class share investable firms do not experience an "investable premium". They may well do so relative to just non-investable dual-class firms. In Table 5, I explore this possibility. Here, I partition the original sample into two distinct groups. In the first group, I exclude all single-class share firms (investable and non-investable) and keep just dual-class share firms. In the second, I exclude all dual-class share firms (investable and non-investable) and keep just single-class share firms. The coefficient estimates for single-class firms confirm what we already know; these firms enjoy large "investable premia". Interestingly, dual-class firms enjoy an "investable premium" relative to other dual-class firms. Using both investable and degree-open factors to measure openness to foreign investment, the coefficient estimates are positive and statistically significant. In fact, they also reveal, relative to their peers, dual-class firms outperform single-class share investable firms (compare 0.286 versus 0.171 , and 0.257 versus 0.122 ). ${ }^{16}$ In part,

\footnotetext{
15 The sample size now drops to 9,523 firm-year observations when I exclude dual-class share investable firms and 8,100 when I exclude single-class share investable firms.

${ }^{16}$ In unreported results, I also show that these results hold when I also account for indirect investability, namely cross-listings in the U.S. and the availability of a country-fund. The results are available from me upon request.
} 
this is consistent with King and Segal (2009) who document large cross-listing premia for dual-class cross-listing Canadian firms. The difference between investable dual-class firms and cross-listing dualclass firms is that the cross-listing firms bond to provide greater disclosures and subject themselves to greater scrutiny as a result of exchange listing in the U.S. In contrast, investability is not necessarily associated with such explicit bonding mechanisms. Consequently, exchange cross-listings (i.e., Level 2/3 ADRs) are associated with much larger valuation gains for dual-class firms.

The results thus far are in line with prior expectations. Well-governed firms reap the largest gains from becoming investable. Relative to the entire sample of firms, dual-class firms do not experience any valuation gains, although, relative to their peers (i.e., other dual-class non-investable firms), they do. In the next section, I examine whether these findings manifest when I use alternative measures of corporate governance.

Table 6 contains the coefficient estimates using the agency cost proxies. In this section, I follow a similar approach to Mitton and O'Connor (2011). ${ }^{17}$ I re-estimate Eq. (1), but now for investable firms who are either well-governed (their pre-investable agency cost/governance measure is above (below) the sample median using sales-to-assets (operating expenses-to-sales) or poorly-governed (their preinvestable agency cost measure is below (above) the sample median using sales-to-assets (operating expenses-to-sales). A priori, I would expect that the coefficient on the investable dummy (degree-open factor) to be greatest for firm with low pre-investable agency costs (i.e. better corporate governance). This is in fact what I find. ${ }^{18}$ In all regressions, the control variables are included, but only reported using the investable dummy regressions for brevity sake. The coefficient estimates suggest that it is only better-governed firms that experience valuation gains from becoming investable. Using both agency cost measures, the coefficient estimates for the better-governed firms (Above-median sales-toassets and below-median operating expenses-to-sales) are both positive and statistically significant. In contrast, the coefficient estimates on the investable dummy for pre-investable poorly governed firms are smaller, and statistically insignificant. Specifically, using the investable dummies, the coefficient estimates on the investable dummy for better-governed investable firms (i.e., Above-median sales-to-assets and below-median operating expenses-to-sales) are 0.196 and 0.186 , respectively. In contrast, for poorly governed firms (i.e., Below-median sales-to-assets and above-median operating expenses-to-sales) the coefficient estimates are much smaller (0.086 and 0.037 , respectively) and statistically indifferent to zero. The same holds when I use the degree-open factors. In summary, these results, together with the findings presented in Tables 4 and 5 suggest that the "investable premia" documented by Mitton and O'Connor (2011) is much higher for single-class share firms, and better-governed firms in general.

\section{Concluding remarks}

Over the course of the last two decades, a sizable literature has demonstrated how financial liberalization reforms have proved beneficial for firms. One such reform, namely stock market liberalizations have served to reduce the cost of equity capital for firms, reduced their financing constraints, which in turn has fostered greater investment, and ultimately has increased their value. However, subsequent work has suggested that the benefits are not as large as expected, and that agency conflicts at both the country and firm level may explain these findings. In this paper I examine whether agency conflicts at the level of the firm impacts on the size of the "investable premia" documented by Mitton and O'Connor (2011). Using a sample of Korean firms, Bae and Goyal (2010) find that better-governed firms reap the largest gains following the liberalization of the Korean stock market. Using firm-specific measures of stock market liberalizations, and employing 251 investable firms across 20 different countries, I do likewise.

Using three measures to proxy for the extent of agency conflicts, I show that the "investable premia" documented by Mitton and O'Connor (2011) is greatest for transparent, well-governed and singleclass share firms. In contrast, for poorly governed firms the benefits are much lower. Stock market

\footnotetext{
17 Mitton and O'Connor (2011) perform a similar exercise for investable firms using (pre-investable) measures of financing constraints.

${ }^{18}$ For comparison sake, I also present the coefficient estimate for the entire sample of firms.
} 
liberalizations do increase the value of dual-class share firms, at least relative to their peers, but their "investable premia" are much lower than that of single-class share firms. The findings are in line with recent evidence, which demonstrates that outside investors, most notably institutional investors prefer to invest in single-class share, and well-governed firms (Li et al., 2008). For these firms, the resulting investment results in large "investable premia". Furthermore these findings suggest that more attention should be paid by firms to improving their corporate governance prior to investability, so that firms can extract the largest gains possible from stock market liberalizations.

\section{References}

Aggarwal, R., Klapper, L., Wysocki, P., 2005. Portfolio preferences of foreign institutional investors. J. Bank Financ. 29, $2919-2946$. Ang, J., Cole, R., Lin, J., 2000. Agency costs and ownership structure. J. Financ. 55, 81-106.

Bae, K., Bailey, W., Mao, C., 2006. Stock market liberalization and the information environment. J. Int. Mon. Financ. 25, $404-428$. Bae, K., Goyal, V., 2010. Equity market liberalization and corporate governance. J. Corp. Financ. 16, 609-621.

Bartram, S., Brown, P., How, J., Verhoeven, P., 2008. Agency Conflicts and Corporate Payout Policies: A Global Study. Working Paper. Lancaster University.

Bekaert, G., Harvey, C.R., 2000. Foreign speculators and emerging equity markets. J. Financ. 55, 565-613.

Bekaert, G., Harvey, C., Lundblad, C., 2001. Emerging equity markets and economic development. J. Dev. Econ. 66, 465-504

Bekaert, G., Harvey, C., Lundblad, C., 2005. Does financial liberalization spur economic growth? J. Financ. Econ. 77, 3-55.

Bushee, B., Carter, M., Gerakos, J., 2007. Institutional Investor Preferences for Corporate Governance Mechanisms. Working Paper. The Wharton School, University of Pennsylvania.

Chamberlain, G., 1984. Panel Data. In: Griliches, Z., Intriligator, M.D. (Eds.), Handbook of Econometrics, North Holland, vol. 2 , pp. $1247-1318$.

Chari, A., Henry, P.B., 2004. Risk sharing and asset prices: evidence from a natural experiment. J. Financ. 59, 1295-1324.

Chiang, Y., Lo, C., 2009. An empirical study of equity agency costs and internationalization: evidence from Taiwanese firms. Res. Int. Bus. Financ. 23, 369-382.

Davies, R.B., Ionascu, D., Kristjansdottir, H., 2008. Estimating the impact of time-invariant variables on FDI with fixed effects. Rev. World Econ. 144, 381-407.

DeAngelo, H., DeAngelo, L., 1985. Managerial ownership of voting rights: a study of public corporations with dual classes of common stock. J. Financ. Econ. 14, 33-39.

Doidge, C., Karolyi, G., Stulz, R., 2004. Why are foreign firms listed in the U.S. worth more? J. Financ. Econ. 71, 205-238.

Doidge, C., Karolyi, G., Stulz, R., 2007. Why do countries matter so much for corporate governance? J. Financ. Econ. 86, 1-39.

Doidge, C., Karolyi, G., Stulz, R., 2009. Has New York become less competitive in global markets? Evaluating foreign listing choices over time. J. Financ. Econ. 91, 253-287.

Durnev, A., Kim, E., 2005. To steal or not to steal: firm attributes, legal environment, and valuation. J. Financ. 60, 1461-1493.

Durnev, A., Kim, E., 2007. Explaining differences in the quality of governance among companies: evidence from emerging markets. J. Appl. Corp. Financ. 19, 16-24.

Edison, H., Warnock, F., 2003. A simple measure of the intensity of capital controls. J. Emp. Financ. 10, 81-103.

Erkens, D., Hung, M., Matos, P., 2010. Corporate Governance in the 2007-2008 Financial Crisis: Evidence from Financial Institutions Worldwide. Working Paper. University of Southern California.

Fazzari, S., Hubbard, G., Petersen, B., 1988. Financing constraints and corporate investment. Brookings Papers on Economic Activity 1, 141-195.

Ferreira, M., Matos, P., 2008. The colors of investors' money: the role of institutional investors around the world. J. Financ. Econ. 88, 499-533.

Gillan, S., Starks, L., 2003. Corporate governance, corporate ownership, and the role of institutional investors: a global perspective. J. Appl. Financ. 13, 4-22.

Gozzi, J.C., Levine, R., Schmukler, S.L., 2008. Internationalization and the evolution of corporate valuation. J. Financ. Econ. 88, 607-632.

Grossman, S., Hart, O., 1988. One share-one vote and the market for corporate control. J. Financ. Econ. 20, 175-202.

Gupta, N., Yuan, K., 2009. On the growth effect of stock market liberalizations. Rev. Financ. Stud. 22, 4715-4752.

Harvey, C., Lins, K., Roper, A., 2004. The effect of capital structure when expected agency costs are extreme. J. Financ. Econ. 74, $3-30$.

Henry, P.B., 2000. Do stock market liberalizations cause investment booms? J. Financ. Econ. 58, 301-334.

Hope, O., Kang, T., Kim, J., 2010. Voluntary Disclosure Practices by Foreign Firms Cross-Listed in the United States. Working Paper. University of Toronto.

Kim, E., Signal, V., 2000. Does financial liberalization reduce financing constraints? Financ. Manage. 32, 5-34.

Kim, B., Kenny, L., 2007. Explaining when developing countries liberalize their financial equity markets. J. Int. Financ. Mkts. Inst. Money 17, 387-402.

King, M., Segal, D., 2009. The long-term effects of cross listing, investor recognition, and ownership structure on valuation. Rev. Financ. Stud. 22, 2393-2421.

Klapper, L., Love, I., 2004. Corporate governance, investor protection and performance in emerging markets. J. Corp. Financ. 10 , 703-728.

Kling, G., Weitzel, U., 2011. The internationalization of Chinese companies: firm characteristics, industry effects and corporate governance. Res. Int. Bus. Financ. 25, 357-372.

Lang, M., Lins, K., Miller, D., 2003. ADRs, analysts, and accuracy: does cross listing in the U.S. improve a firm's information environment and increase market value? J. Account Res. 41, 317-345. 
Lensink, R., van der Molen, R., 2010. Does group affiliation increase firm value for diversified groups? New evidence from Indian companies. J. Empiric. Financ. 17, 332-344.

Leuz, C., Lins, K., Warnock, F., 2009. Do foreigners invest less in poorly governed firms? Rev. Financ. Stud. 22, $2393-2421$.

Li, K., Ortiz-Molina, H., Zhao, X., 2008. Do shareholder rights affect institutional investment decisions: evidence from dual-class shares? Financ. Manage. 37, 713-745.

Lins, K., 2003. Equity ownership and firm value in emerging markets. J. Financ. Quant. Anal. 38, 159-184.

Masulis, R., Wang, C., Xie, F., 2009. Agency costs at dual-class companies. J. Financ. 64, 1697-1727.

McCahery, J., Sautner, Z., Starks, L., 2009. Behind the Scenes: The Corporate Governance Preferences of Institutional Investors. Finance Working Paper No: 235/2009. European Corporate Governance Institute.

McKnight, P., Weir, C., 2009. Agency costs, corporate governance mechanisms and ownership structure in large UK publicly quoted companies: a panel data analysis. Quart. Rev. Econ. Financ. 49, 139-158.

Mitton, T., 2006. Stock market liberalization and operating performance at the firm level. J. Financ. Econ. 81, 625-647.

Mitton, T., O'Connor, T., 2011. Investability and firm value. Eur. Financ. Manage., in press.

Mundlak, Y., 1978. On the pooling of time series and cross section data. Econometrica 1, 69-85.

O'Connor, T., 2010. Are there permanent valuation gains from becoming investable? Bank Financ. Letters 2, 419-429.

Patro, D., 2005. Stock market liberalization and emerging market country fund premiums. J. Bus. 78, 135-168.

Petersen, M.A., 2009. Estimating standard errors in finance panel data sets: comparing approaches. Rev. Financ. Stud. 22, 435-480.

Plumper, T., Troeger, V., 2007. Efficient estimation of time-invariant and rarely changing variables in finite sample panel analyses with unit fixed effects. Pol. Anal. 15, 124-139.

Plumper, T., Troeger, V., 2011. Fixed-effects vector decomposition: properties, reliability, and instruments. Pol. Anal. 19, 147-164.

Singh, M., Davidson, W., 2003. Agency costs, ownership structures and corporate governance mechanisms. J. Bank. Financ. 27, 793-816.

Smart, S., Thirumalai, R., Zutter, C., 2008. What's in a vote? The short and long run impact of dual-class equity on IPO firm values. J. Account. Econ. 45, 94-115.

Stulz, R., 2005. The limits to financial globalization. J. Financ. 60, 1595-1638. 